\title{
Impact Assessment of Domestic Wastewater use for Irrigation in Kandahar City, Afghanistan
}

\author{
Ahmad Fawad Ehsas \\ ${ }^{1}$ (Ministry of Higher Education, Afghanistan Higher Education Development Program (HEDP), Water and \\ Environmental Engineering Department, Engineering Faculty, Kandahar University, Afghanistan
}

\begin{abstract}
Both primary and secondary data were collected from all 10 districts of Kandahar city. Three Hundred Eighty Seven (387) questionnaires survey was conducted as primary data collection and twelve government and International offices were visited for secondary data collection. Rapid urbanization, population growth and lack of urban planning has caused pollution in former irrigation ditches, where wastewater has been mixed into former irrigation ditches flowing together thus used in agriculture. Wastewater direct use in agriculture has resulted diseases in agriculture production such as wheat diseases, pomegranate worms and slow growth of plants. According to farmers due to increase of wastewater in irrigation ditches, their agriculture production has reduced to 50\% comparing to past. According to current research it was found that the diseases from wastewater were 38\% diarrhea, $16 \%$ Cholera, $15 \%$ Malaria/Typhoid, $18 \%$ other diseases and $4 \%$ bloody diarrhea accordingly. Wastewater direct use has caused various economic issues to the residents of Kandahar City. According to current research $58 \%$ residents complain from diseases, $19 \%$ residents complain from agriculture soil damage, $3 \%$ residents complain that they spent extra money for sanitation, only $19 \%$ residents said that there is no economic impact from wastewater usage.
\end{abstract}

Keywords: - Wastewater, Irrigation, Agriculture, Disease, Economic Issues

\section{INTRODUCTION}

Through increasing global population, the gap between the supply and demand for water is broadening and is getting such alarming levels that in some parts of the world it is posing a risk to human existence. Scientists around the globe are working on new ways of protecting water. It is an opportune time, to refocus on one of the ways to recycle water through the reuse of urban wastewater, for irrigation and other purposes. This could discharge clean water for use in other sectors that need fresh water and provide water to sectors that can consume wastewater e.g., for irrigation and other ecosystem services (Hussain et al., 2002, Metcalf and Eddy, 2004 ). More than $10 \%$ of the world's population consumes foods produced by irrigation with wastewater. The percentage will be noticeably higher among populations in low-income countries with arid and semi-arid climates. Both treated and untreated wastewater are used directly and indirectly (i.e. as faecally contaminated surface water) for irrigation in developed and less developed countries (WHO, 2006). The main task facing the agricultural sector is not as much growing $70 \%$ more food in 40 years, but making $70 \%$ more food accessible on the plate. Decreasing losses in storage and along the value chain may go a long way towards balancing the need for more production (WWAP, 2012). The run through of cleaning and reusing water that has been polluted by household or agricultural use can noticeably drop call on aquifers and decrease the volume of effluent that is discharged into streams, rivers and lakes, sponsoring to the safety of ecosystems (Lazarova et al., 2001). In recent times, the reuse of grey wastewater $(\mathrm{GW})$ for irrigation purposes has taken on growing care as a means of water protection. GW represents the largest possible source of water savings in domestic residences, accounting for as much as 50-80\% of the total water uses (Eriksson et al., 2002, Ulrich et al., 2009). In 1979, The Organization of Eminent Scholars of Saudi Arabia well thought-out the question of treated wastewater reuse and issued a religious ruling (Fatwa) in the Daily Newspaper, Al-Madina, Jeddah, on 17 April, 1979. The Fatwa permitted the reuse of treated wastewater (water that is non-turbid, and has been sufficiently diluted with clean water or has been visible to the natural elements for sufficient periods) for all purposes even for religious washings (Mara, 2004 and Hussain et al., 2002). Kandahar city is the capital of Kandahar province, and the former capital and second largest city in Afghanistan. Kandahar city is situated in the southeastern area of Afghanistan at approximately 1005 meters above sea level. In recent years, the city has experienced population fluctuation due to influxes of displaced persons and refugees caused by war and drought. Kandahar is a province with limited water resources. Arid climate variable precipitation and periodic droughts all make it difficult to predict the availability of water in the region over time (USACE, 2011). The environment and public health are poorly impacted by the lack of sufficient wastewater systems and improper management of the existing systems. High population density, narrow streets, and lack of right of ways will be challenges to improving the city's 
drainage. Diseases such as malaria, typhoid, and cholera are widespread. The situation of Kandahar city is getting worse due to population growth, urbanization and increased domestic water use (TTI, 2012). The use of treated sewage for agriculture will increase the food production and will decrease the due fresh water for agriculture, so that the fresh water can be used for other purposes, where ever extremely required (Ehsas, 2013). The purpose of this research was to review the current condition of former irrigation ditches and to assess impacts of municipal wastewater use for irrigation purpose in Kandahar City, Afghanistan. The findings of this research will help other researchers by means of secondary data, in addition the condition of former irrigation ditches and impacts of municipal wastewater use for irrigation in Kandahar is assessed for the first time, which will definitely help the directorates of irrigation, agriculture, public health and Kandahar Municipality for their researches and practical work.

\section{METHODOLOGY}

Based on the objectives listed in the chapter 1, review the current condition of former irrigation ditches and assess impacts of Municipal Wastewater use for irrigation purpose in Kandahar City were focused accordingly. The overall methodology is described in Fig. 1.

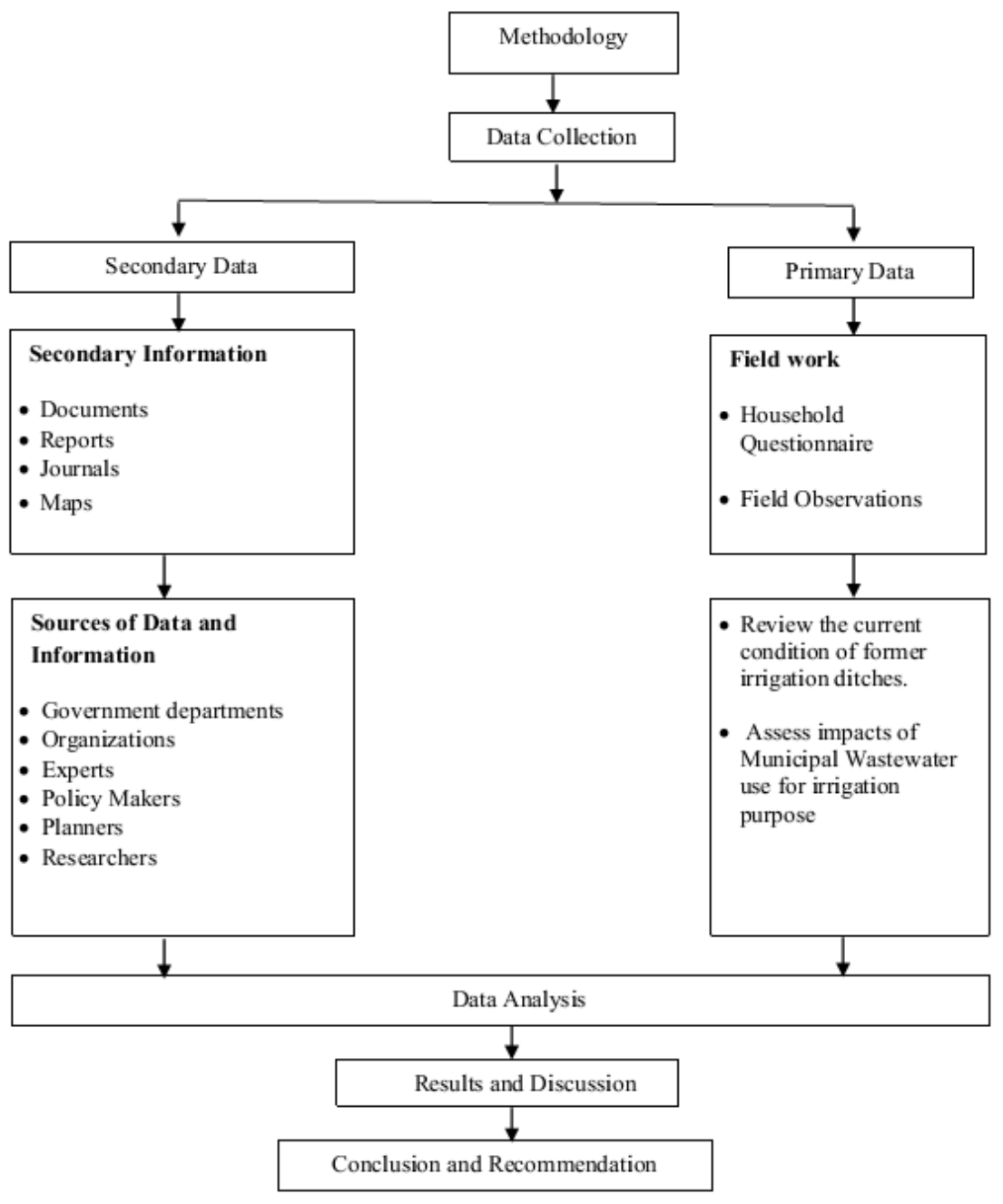

Figure 1: Methodology Framework

\subsection{Data Collection}

Both primary and secondary data were collected from all 10 districts of Kandahar city. The purpose of data collection was to review the current condition of former irrigation ditches and assess impacts of Municipal Wastewater use for irrigation purpose in Kandahar City.

\subsection{Secondary Data Collection}


The data from documents, reports, journals and maps were used as secondary data; furthermore data was collected from government departments, organizations, experts, policy makers, planners and researchers, totally 12 offices were visited during the secondary data collection, they are as followings:

1) Department of Kandahar Municipality

2) Department of Public Works

3) Department of Rural Development

4) Department of Urban Development

5) Department of Public Health

6) Department of Environment Protection

7) Department of Water Supply

8) Department of Irrigation

9) Department of Agriculture

10) Aino Mina New Kandahar city project

11) United Nations Human Settlements Programme Office (UN-HABITAT)

12) World Health Organization Office (WHO)

\subsection{Primary Data}

Primary data is really important for the study; it helps to realize the real and current situation of the study area. The primary data includes direct observation of the site, group discussion, and interview with the local people, head and officers of the community and public health officers. The primary data includes the followings:

\subsubsection{Field Observations and Site Visits}

For the purpose of getting adequate information about study area, the focus is on:

- Living condition of households

- Current situation of sanitation system

- Excreta collection and disposal

- Current condition of wastewater ditches

- Current condition of farmer irrigation ditches

- Environmental condition of the study area

- Wastewater collection, discharge and treatment

\subsubsection{Interview (Questionnaire)}

Questionnaires were used for primary data collection. Questionnaire survey was undertaken; the plan was to use randomly selected households in the selected district, the houses are the representatives to the district, because the households have different living conditions such as rich, poor and normal household conditions. The questionnaire was mainly prepared for local residents. Questionnaire was distributed into household's occupants, schools, hospitals, private sectors and nongovernmental organizations (NGOs). Due to the limitation of time and budget, the interview was done for limited households because interviewing all the households in the selected district area requires enough time and budget. Sampling bias sampling method is used, site is divided into various parts but due to lake of population names lists, sampling bias or non-random sampling method is applied. According to Haziq (2012) the total population of 10 districts is 113,400 (Table 1) which is the selected population, hence the study population one family in 300 families, thus total 387 families are the study population of this study.

Table 1 Kandahar Districts Survey Statistics (Haziq, 2012)

\begin{tabular}{|c|c|c|c|c|c|c|}
\hline District & $\begin{array}{c}\text { High } \\
\text { Income } \\
(\boldsymbol{\%})\end{array}$ & $\begin{array}{c}\text { Medium } \\
\text { Income (\%) }\end{array}$ & $\begin{array}{c}\text { Low } \\
\text { Income } \\
(\boldsymbol{\%})\end{array}$ & $\begin{array}{c}\text { Registered } \\
\text { Households }\end{array}$ & $\begin{array}{c}\text { Unregistered } \\
\text { Households }\end{array}$ & Total Households \\
\hline $\mathbf{1}$ & 60 & 20 & 20 & 6,532 & 5,468 & 12,000 \\
\hline $\mathbf{2}$ & 50 & 20 & 30 & 2,277 & 12,723 & 15,000 \\
\hline $\mathbf{3}$ & 40 & 30 & 30 & 6,500 & 5,500 & 12,000 \\
\hline $\mathbf{4}$ & 40 & 40 & 20 & 5,100 & 2,100 & 7,200 \\
\hline $\mathbf{5}$ & 60 & 20 & 20 & 2,800 & 3,200 & 6,000 \\
\hline
\end{tabular}




\begin{tabular}{|c|c|c|c|c|c|c|}
\hline $\mathbf{6}$ & 30 & 40 & 30 & 651 & 5,349 & 6,000 \\
\hline $\mathbf{7}$ & 30 & 30 & 40 & 1,600 & 4,900 & 6,500 \\
\hline $\mathbf{8}$ & 30 & 30 & 40 & 1,000 & 4,700 & 5,700 \\
\hline $\mathbf{9}$ & 20 & 20 & 60 & 15,000 & 15,000 & 30,000 \\
\hline $\mathbf{1 0}$ & 15 & 20 & 65 & 5,600 & 7,400 & 13,000 \\
& & & & & $\mathbf{1 1 3 , 4 0 0}$ \\
\hline
\end{tabular}

\subsection{Data Analysis}

The data which was collected by standardized questionnaire and site visits are checked and verified before coding process. Data entry and processing are done through the application of the SPSS and Microsoft Excel programs for graphic presentation of data.

\section{RESULTS AND DISCUSSION}

The results are categorized according to the objectives, the chapter starts with the findings for the first and second objectives such as review the current condition of former irrigation ditches and assess impacts of Municipal Wastewater use for irrigation purpose in Kandahar City. The results for first and second objectives were achieved through 387 questionnaires survey and field visits then the questionnaires were analyzed by Statistical Package for the Social Science (SPSS) and Ms. Excel programs.

\subsection{Review of Current condition of Farmer Irrigation Canals in Kandahar City}

Most of Irrigation ditches pass through Kandahar City, thus in some areas wastewater is mixed to the irrigation ditches. During the field visits it is clear that agricultural lands are located inside and outside Kandahar city. All the irrigation ditches source is Arghandab River, the irrigation ditches converted in the Baba Sahib and finally they are further divided into smaller ditches in district 8th such as Panjab, Sarkari, Sarkozi, Mashore, Nakodak, Rohabad and Noshijan ditches. Mentioned ditches pass through 8th, 7th, 6th, 2nd and 3rd districts and finally reach to Dand district's agriculture lands.In addition there are two canals such as City's central canal and Tagir canal which reach until 1st district and finally mix with the city's general canal. Other ditches which pass through center of city or other districts, their source point is district 9th and finally mix to the general canal of the Kandahar City, thus it is all together used for irrigation purpose in Kandahar City and outside Kandahar City. Besides above mentioned ditches other ditches start from district 10th, pass through some areas of city, finally flow outside of the city. In order to explain the characteristics and issues of all the ditches, it is started from the ditches which is at the first starting part and then come down accordingly to the last ditches. Through site visits the general map of the city is drawn, which include irrigation ditches, drainage, wastewater ditches and mixed irrigation and wastewater ditches. In the map Kandahar city is divided into 10 districts, thus the ditches are shown which pass through each district. It is clear that the flow direction of wastewater ditches is from North towards South and South West of Kandahar City (Fig 2, 3 \&4).

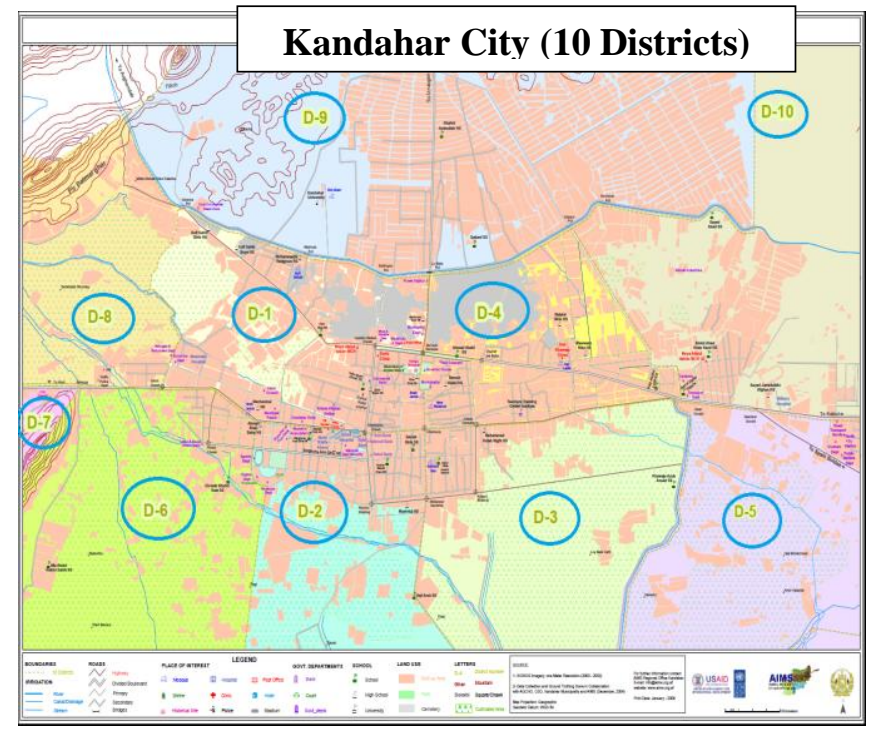

Figure 2: Study Area (10 Districts), Kandahar City 


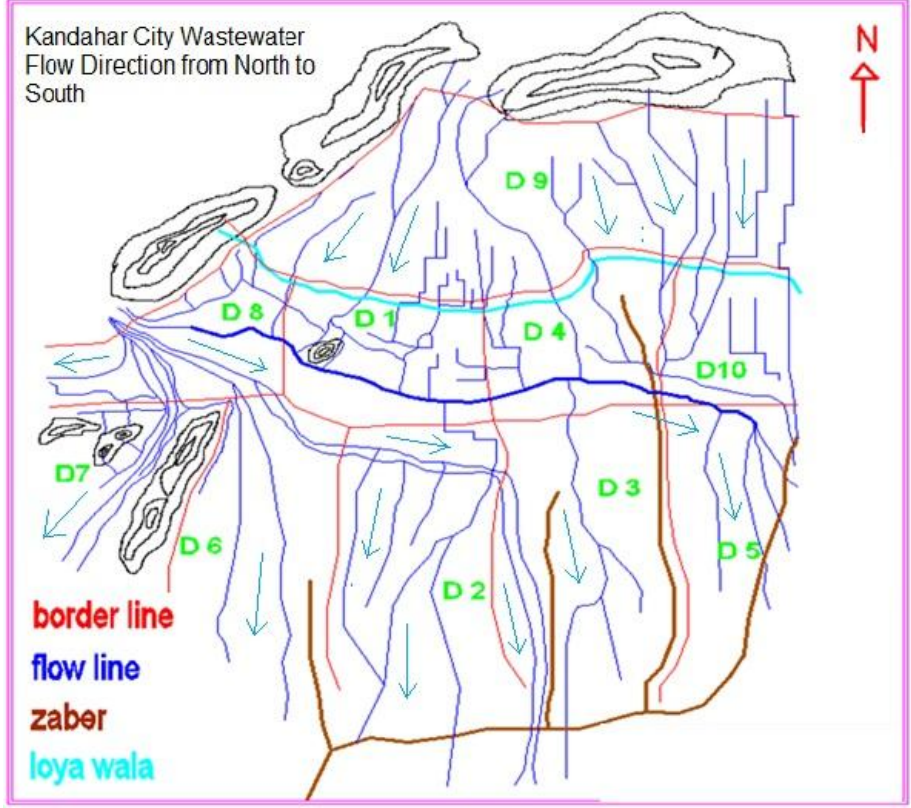

Figure 3: Wastewater Flow direction in Kandahar City, Afghanistan.

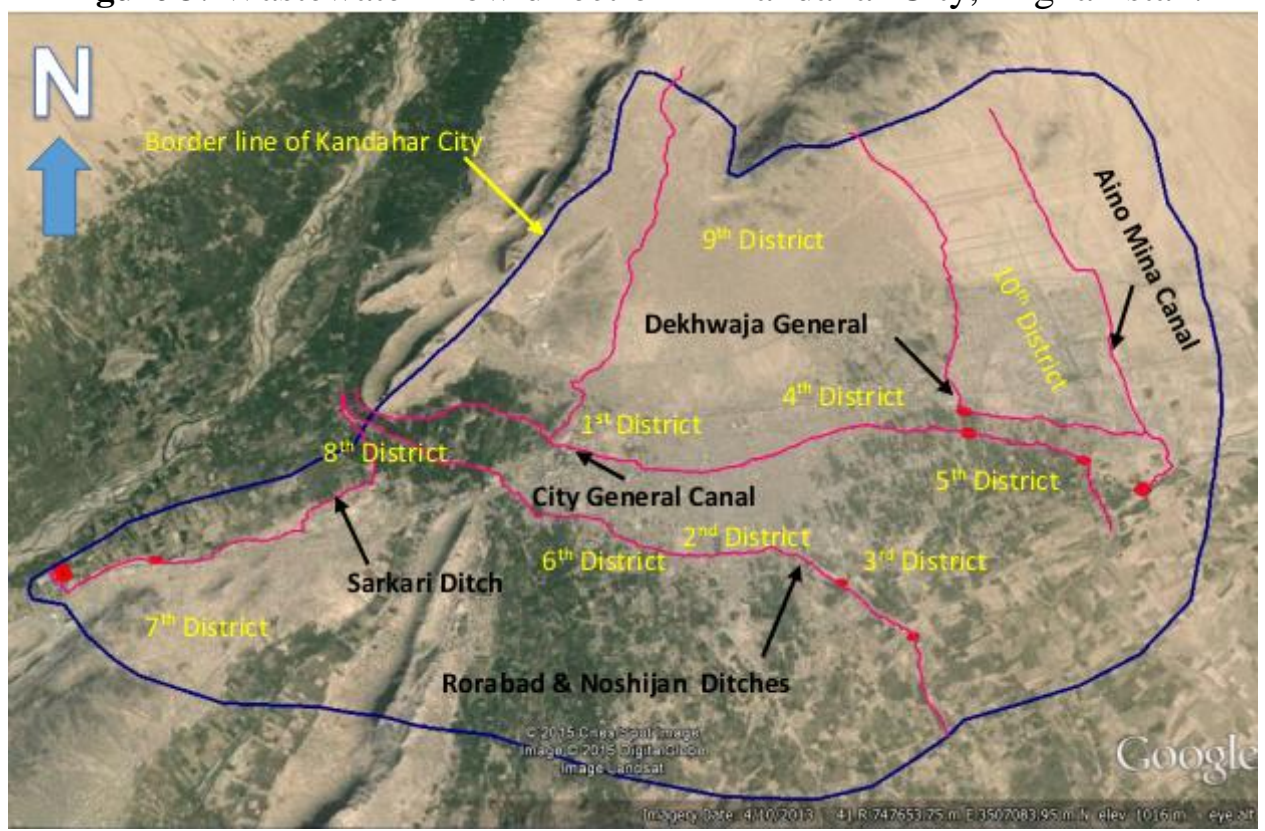

Figure 4: Large mixed irrigation and wastewater ditches in Kandahar City

\subsection{Impacts Assessment of Wastewater use for irrigation purpose in Kandahar City}

Wastewater was not considered as an issue at Kandahar city in past decades, Environment and Health were not affected by wastewater. In recent years due to security concerns, population increase, displacement immigrants and fast urbanization water usage increased thus resulted into wastewater formation. Usage of more water resulted into scarcity of water hence residents were compiled to use wastewater in agriculture, which caused Environmental, Social and economic issues in Kandahar City.

\subsubsection{Impacts on Human Health}

The results of data collection showed that the major disease in Kandahar city is Diarrhea and bloody diarrhea which is commonly due to drinking water. There is no wastewater treatment plant in Kandahar city, therefore wastewater is directly used for irrigation purpose, and on the other hand wastewater infiltration to the drinking water is also the reason of above mentioned diseases (Fig.5). 


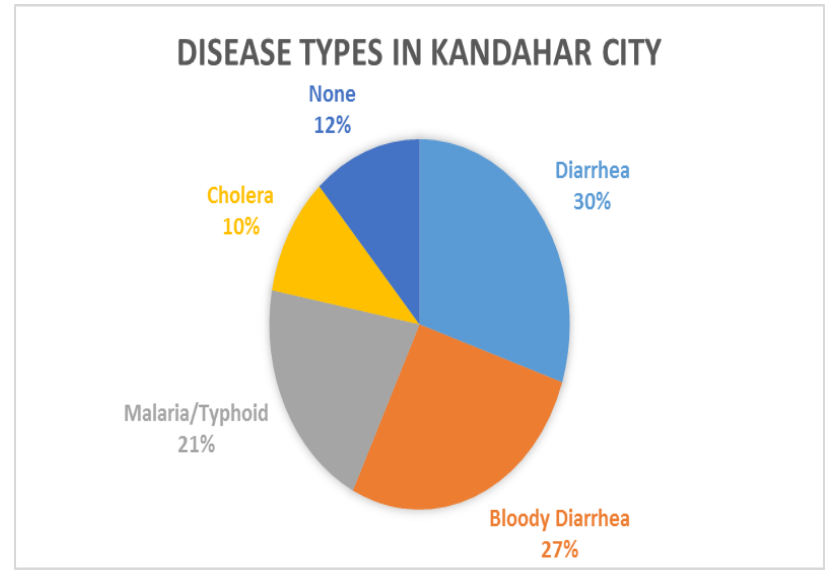

Figure 5: Types of Diseases in Kandahar City

The (Fig. 6) shows the results of questionnaire for the consequences of wastewater use in agriculture.

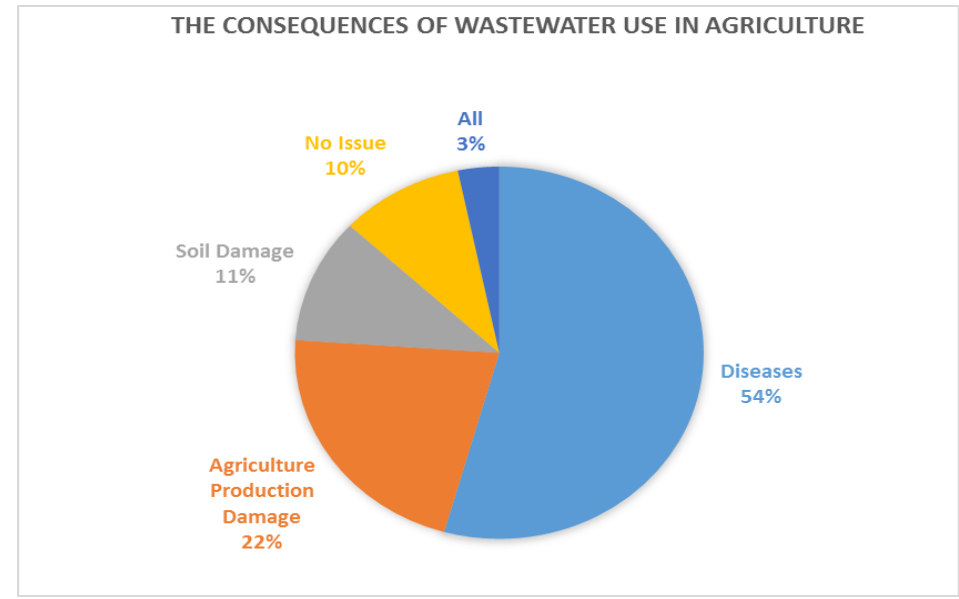

Figure 6: Impacts of Wastewater direct use in agriculture

\subsubsection{Impacts on Dairy Farms}

As it is mentioned early in chapter two that wastewater use can cause parasites and viruses, the common ones are worms which transfer to human body through hosts. They grow in human body and then spread to others. Through questionnaire survey it was mentioned that direct use of wastewater in agriculture has caused various diseases in milk cows. Dr. Abdul Zahir the owner of animal clinic said in the interview that the main reason of cow's diseases is the direct use of wastewater in the grass, in addition during milking the cow lack of sanitation is another cause of cow's diseases (Fig. 7).

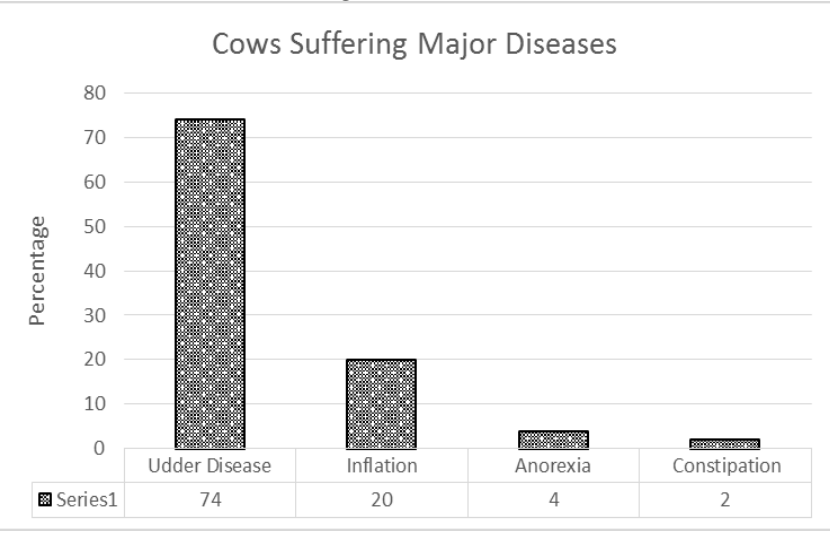

Figure 7: Dairy Cows Diseases in Kandahar City 


\subsubsection{Economic Impacts}

The major economic impacts of wastewater direct use in agriculture are Expenses on human and animal diseases and damage to agriculture production. In the study it was observed that the wheat form has been infected with disease because of direct use of wastewater, it is an economic impact because both soil and agriculture production are damaged due to wastewater direct use. Another economic impact of wastewater direct use in agriculture is the expenses for treatment of patients going to doctor. The (Fig. 8) clearly shows that $33 \%$ residents go to doctor every month, $32 \%$ residents visit doctor once in two months and $14 \%$ residents visit doctor once in six months. It is clearly indicating the expenses for treatment.

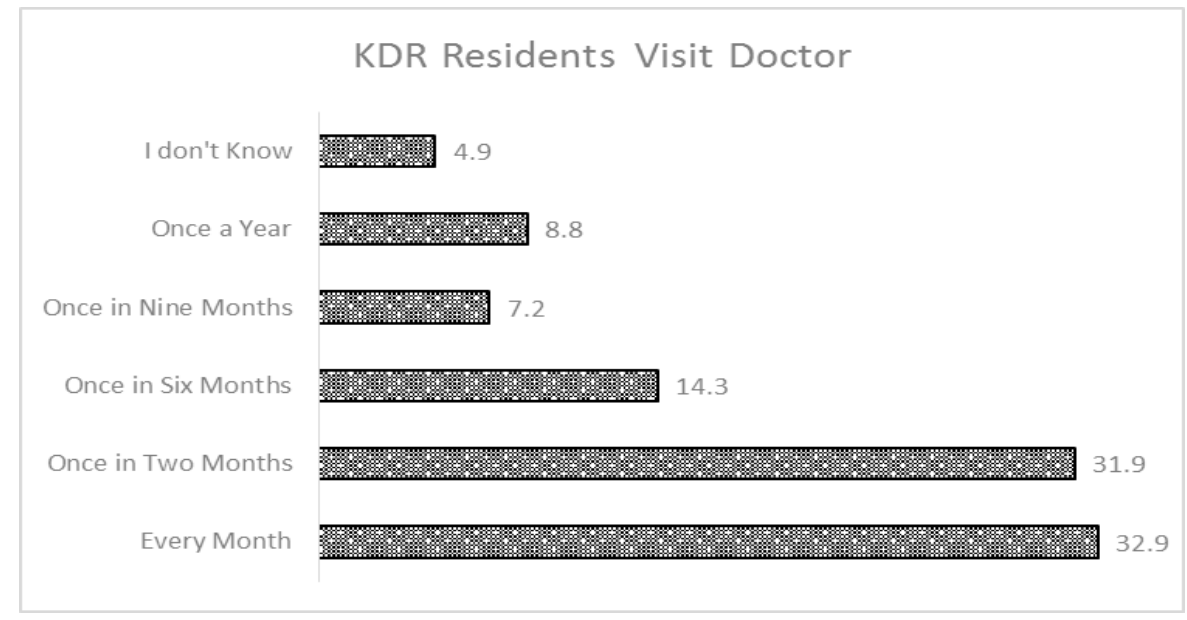

Figure 8: Kandahar City Residents Visit Doctor

\subsubsection{Environmental Impacts}

Environment of Kandahar city is not suitable because of inadequate drainage and ditch system of wastewater, it has caused bad smell, flies, mosquitoes and various diseases. In most of the districts it is observed that due to the inadequate drainage system, wastewater flow in the streets, which has caused various environmental issues. Damage to the soil is another subject which is related to environment, due to wastewater use in agriculture most of the agriculture soil are damaged hence salinity increased which resulted into loss of productivity. During summer season when wastewater is flowing due to inadequate ditch system, flies and Mosquitoes use it as their host, hence result into human diseases such as Malaria and Typhoid and plant diseases from flies. According to the results of questionnaire, $83 \%$ residents said that Wastewater usage has impacts on environment (Fig. 9).

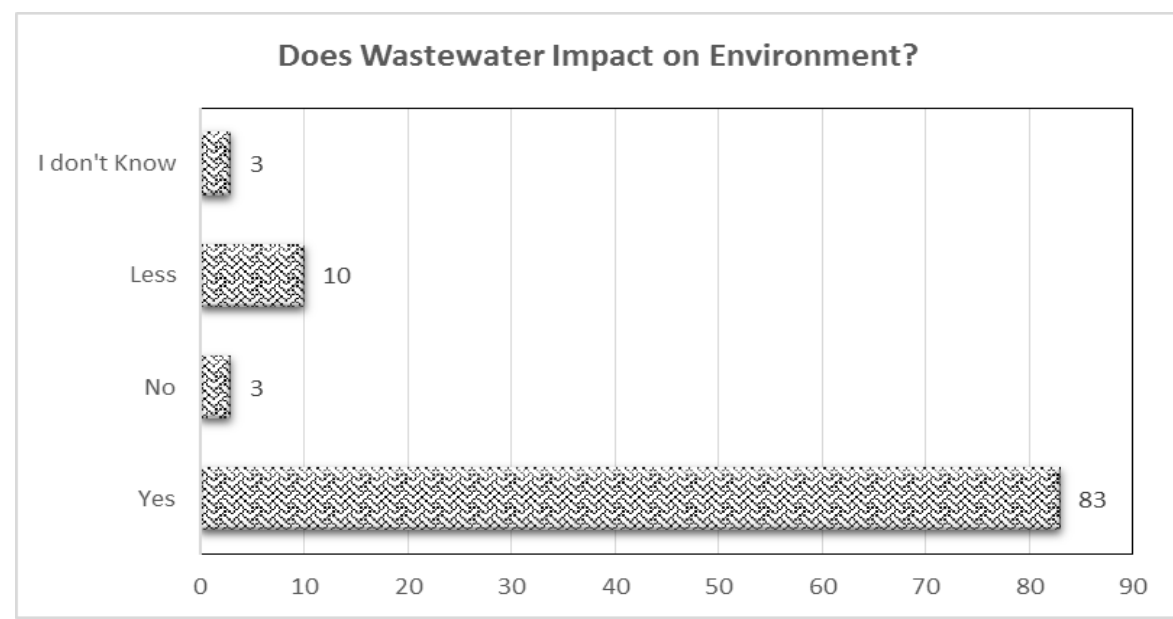

Figure 9: Wastewater Impacts on Environment 


\section{CONCLUSION}

The main focus of recent study was to review the current condition of former irrigation ditches and to assess impacts of municipality Wastewater use for irrigation purpose in Kandahar City. All 10 districts of Kandahar city were observed through site visits and questionnaire survey where 378 questionnaire were distributed during this research. During the survey it was observed that the former irrigation ditches are used for both wastewater and irrigation water which is used for irrigation purpose, hence reduced the productivity of agriculture. On the other hand environment has been facing various challenges due to wastewater flowing without adequate drainage system causing flies, mosquitoes and bad smell production in Kandahar city. In addition the economic impacts of wastewater such as expenses for treatment spent during doctor visits and soil damage were discussed earlier accordingly.

\section{ACKNOWLEDGMENT}

The author gratefully acknowledges Higher Education Development Program (HEDP) for the fund support of this research. The author really appreciates the HEDP management and support during the research, on the other hand it is a great opportunity for Afghan lecturers to conduct researches through mentioned fund supports, it will add to the capacity of Afghan lecturers, furthermore will encourage research projects to be conducted by Afghans in Afghanistan. In addition, the author would also like to pay his best regards to all his friends, colleagues, students and group members for their encouragement and extended help. Last but not least, the author would like to convey his sincere gratitude to his beloved parents and family for their endless love, moral support, continuous inspiration, prayers, patience and understanding throughout the entire period of research project.

\section{REFERENCES}

[1] Hussain I.; L. Raschid; M. A. Hanjra; F. Marikar; W. van der Hoek. 2002. Wastewater use in agriculture: Review of impacts and methodological issues in valuing impacts. (With an extended list of bibliographical references). Working Paper 37. Colombo, Sri Lanka: International Water Management Institute.

[2] Metcalf and Eddy. (2004). Wastewater Engineering: Treatment, Disposal and Reuse, (4th Edition), Singapore: McGraw Hill, Inc, ISBN: 0-07-124140-X

[3] WHO (World Health Organization), (2006). Guidelines for the safe use of wastewater, excreta and greywater: Volume 2 Wastewater use in agriculture. France.

[4] World Water Assessment Programme (WWAP) (2012). The United Nations World Water Development Report 4: Managing water under Uncertainty and Risk. Paris, UNESCO.

[5] Lazarova, V., Levine, B., Sack, J., and Cirelli, G. (2001). Decentralized Sanitation and Reuse Concept, System and Implementation, International Water Association publishing, ISBN: 1-900222-47-7.

[6] Eriksson, E., Auffarth, K., Henze, M., and Ledin, A. (2002). Characteristics of Grey Wastewater. Urban water, 4 (1), 85-104.

[7] Ulrich, A., Reuter, S., and Gutterer, B. (2009). Decentralized Wastewater Treatment System (DEWATS) and Sanitation in Developing Countries: A Practical Guide. Water Engineering and Development Centre (WEDC), Loughborough University of Technology, UK

[8] Mara, D. (2004). Domestic Wastewater Treatment in Developing Countries. Earthscan, UK and USA, ISBN 1-84407-019-0 - ISBN 1-84407-020-4.

[9] USACE (United States Army Corps of Engineers), (2011). Kandahar City Water Supply Master Plan, USACE, Kandahar, Afghanistan.

[10] TTI (Tetra Tech Inc), (2012). Kandahar City Wastewater Master Plan. DRAFT Copy for Consultation. TTI, Framingham, United States.

[11] Ehsas, A.F. (2013) Development of low cost community based domestic wastewater for

[12] Kandahar city, Afganistan. (Master thesis, Asian institute of Technology, 2013.Thailand:

[13] Asian institute of Technology.

[14] Haziq, M. A. (2012). Assessment of Household Water Consumption in Kandahar City, Afghanistan. (Master's Thesis No WM-12-03, Asian Institute of Technology, 2012). Thailand: Asian Institute of Technology. 